811.163.41’367.335

https://doi.org/10.18485/mks_srpska_slavistika.2018.1.ch28

Срето 3. ТАНАСИЋ*

Институт за српски језик САНУ, Београд

\title{
БЕЗЛИЧНЕ ПАРТИЦИПСКЕ РЕЧЕНИЦЕ У СРПСКОМ ЈЕЗИКУ ${ }^{* *}$
}

\begin{abstract}
У раду се говори о једном типу безличних реченица у српском језику, које су познате и у другим словенским језицима, а које у српској научној литератури досад нису обрађиване. Оне се помињу тек у новијим граматикама српског језика. То су једночлане реченице, без субјекта, код којих се предикат образује помоћу трпног придјева, и то у безличном облику. Указује се у чему се оне разликују од пасивних партиципских реченица, с којим их понекад изједначују, пореде се с другим реченицама с којим имају додирних тачака, показује начин њиховог образовања и домен употребе.

Кључне речи: српски језик, реченице, безличне партиципске реченице, пасивна дијатеза, обезличавање, неутрализација прелазности.
\end{abstract}

Безличне партиципске реченице у српској научној литератури се практично и не помињу, камоли да су детаљније описиване. То је тим чудније што су добро познате друге реченице с којим се ове реченице на неки начин граниче, какве су пасивне реченице, неодређеноличне реченице и врста безличних рефлексивних реченица, другачије и прецизније прозване у српским граматикама - обезличене реченице. Ради се о реченицама као што су сљедеће:

[1]

1. Нови конзул испраћен је кроз улице псовкама и претњама жена и деце, на њега је пљувано са прозора, а одрасли људи у дућанима нису га удостојили једнога погледа (Андрић, 96);

2. Али давно је речено да слободу није довољно стећи (Андрић, 316);

3. Наређено ми је да те вежем, чича-Аћиме (Ћосић, 95);

4. Речено нам је да треба да бранимо отаџбину (Политика).

\footnotetext{
"sretotanasic@yahoo.com

** Рад је настао у оквиру пројекта 178021 Опис и стандардизаиија савременог српског језика, који се реализује у Институту за српски језик САНУ, а финансира га Министарство просвете, науке и технолошког развоја Републике Србије.
} 
Тешко је објаснити зашто су ове реченице остале изван пажње српских лингвиста и граматичара. Оне се уопште не помињу у великој Стевановићевој Cинтакси, написаној средином двадесетог вијека, мада се јављају и у народним приповијеткама и у књижевним дјелима писаца који су ушли у корпус за писање овог дјела (Глишић, Веселиновић, Ј. Игњатовић, И. Секулић, Кочић, В. Петровић, Андрић, као других писаца - Црњански, Ћопић, Ћосић, Капор итд.) ${ }^{1}$. Исто тако је и са средњошколском граматиком која је у употреби посљедњих тридесетак година (Станојчић, Поповић 2005). Нема оваквих реченица ни у граматици за странце 3. Вукадиновић, али међу примјерима за пасивне реченице наводи се један за овакве реченице: На јучерашњој седници је наглашено (Mrazović, Vukadinović 2009: 167). Кад се узме у обзир чињеница да се у овој граматици пасив дефинише непрецизно: „Ako se želi istaći ono što je obuhvaćeno procesom koji označava glagol ili sam proces, a agens (vršilac radnje) nije poznat ili nije bitan, upotrebljava se pasiv", те да она и реченице типа У овој соби се спава назива неутралним пасивом, није ништа чудно што се ове реченице мешају са пасивним. Јасно је да овакво, традиционално одређење пасива у коме се не прави јасна разлика између семантичког и синтаксичког плана није довољно. Оно садржи два недефинисана појма: субјекат и радњу усмјерену на X (Падучева 1974: 217). Нема јасног истицања карактеристика пасива као дијатезе: промјена семантичке интерпретације субјекта, обавезна употреба прелазних глагола, блокирање ближег објекта и појава валентности за агентивну допуну (Падучева 1974: 225). А. 3. Тополињска истиче „да су падеж и дијатеза (глаголски род) две међусобно тесно повезане граматичке категорије по централној улози која им припада при семантичком и синтаксичком устројавању просте реченице" (Тополињска 1996: 9). Радоје Симић и Јелена Јовановић у обимној двотомној Синтакси доста говоре о безличним реченицама, али такође не помињу овај тип. Истина, говорећи о једном типу безличних реченица, које нису сродне с овим, чији „лични глаголски облици не упућују на 'носиоца' радње" (Већ је свитало; Исплатило би се), наводе један примјер: Свршено је с преровском идилом (Симић, Јовановић: 277). Незахвално је тумачити како су овај предикат, па и безличну реченицу, тумачили аутори. Први пут овакве реченице наводи с другим безличним реченицама и дефинише као безличне Предраг Пипер у Синтакси просте реченице групе аутора. Додуше, у првом дијелу књиге, гдје се говори о моделима просте реченице, међу једночланим, односно безличним реченицама, не наводе се ове реченице. Оне се наводе у другом дијелу књиге, у поглављу о персоналности, као „безличне реченице с партиципским пасивом у именском делу предиката”, за које се каже да „значе стање које је резултат радње чији је носилац неименовани субјекат „имају у глаголском дијелу предиката помоћни или полупомоћни глагол, а у именском дијелу предиката трпни придјев глагола по правилу свршеног вида у једнини и у средњем роду, али понекад и несвршеног вида": О томе је много писано; Са овима је свршено; О томе је одлучено на синоћној седници (Пипер, Антонић и др. 2005: 605). И у најновијој, нормативној граматици српског језика, у одјељку „Значење једночланих простих реченица", међу безличним помињу се и ове под називом пасивне безличне рече-

${ }^{1}$ У поглављу Глаголски род и сродна питањ $а$, говорећи о повратним глаголима, Стевановић наводи и сљедећи примјер: Твојој глави би суђено за вијенац се свој продати (Стевановић 1991: 556). Истина, њега је овдје интересовао други глагол - продати се, па предикат би суђено није ни помињао. 
нице и наводе три примјера: Одлучено је у нашу корист; Било је постављено за четири особе; Замјерано му је што није био одлучнији (Пипер, Клајн 2015: 442). У погледу њихова значења каже се: „Када је у предикату таквих безличних реченица трпни придјев свршеног глагола, оне значе да постоји или не постоји резултат неке радње, чији се вршилац или извор не наводи у облику граматичког субјекта, или се не помиње уопште, а може бити поменут индиректно [...]. Када је у предикату таквих безличних реченица трпни придјев несвршеног глагола, таква безлична конструкција има итеративно значење и представља управни дио зависносложене реченице са допунском клаузом" (2015: 442). Ово што је речено није довољно, што је разумљиво ако се подсјетимо изнесене чињенице да о овим реченицама у српској научној литератури није уопште писано.

Овим реченицама бави се Јасмина Московљевић Поповић у својој књизи о глаголској поткатегоризацији у поглављу о деагентивизацији. Ту се разматрају реченице у којим се агенс уклања помоћу промјене реченичне структуре. Аутор деагентивизацију разматра на оба типа пасивних реченица, те на тзв. обезличеним рефлексивним реченицама и на безличним партиципским реченицама. Све их подводи под исти термин, у сљедећим варијацијама: пасивне конструкиије с партиципским пасивом, конструкције/реченице с партиципским пасивом. Из овога се може извући закључак да Ј. Поповић Московљевић и нема за циљ да утврђује однос између ова два типа реченица, њих обједињује чињеница да су деагентизоване, нпр.: Ivan je popravio kola - Kola su popravljena (2007: 58); Ana je majstoru platila unapred - Majstoru je plaćeno unapred (2007: 59). Дакле, она ове реченице уопште није идентификовала; није је интересовала њихова посебност у односу на пасивне реченице. Са становишта овог рада ова студија је значајна по томе што аутор наводи већи број класа глагола који долазе у овом типу безличних реченица, слабија страна је та што није писан на корпусу; примјери су конструисани.

И то би било све што се у српској литератури може прочитати о овим реченицама. Очито је, дакле, да их је нужно подробније описати, као што су описане и у другим словенским језицима. Речено да се овакве реченице јављају и у другим словенским језицима, ${ }^{2}$ да је о њима писано, да се наводе и у граматичкој литератури. Велика руска граматика их описује међу другим једночланим реченицама (АНСССР Грамматика: 381-383), а Књазев (Князев) их у својој граматици описује под називом безличне конструкције (Князев 2007: 555-561). У новијој књизи о категоријама у граматици А. В. Бондарко помиње ове реченице кад говори о пасивној дијатези као примјер реченица које немају све карактеристике пасива; и он одређење пасива даје у складу са дефиницијом лењинградске школе. Али пошто имају пасивну форму глагола у предикату, он их је смјестио на периферију поља пасивне дијатезе (Бондарко 2011: 178-179)3. Међутим, и сам Бондарко напомиње да се пасив одређује на нивоу реченице. Узгред буди речено, ни форма предиката им није као у пасивној

\footnotetext{
${ }^{2}$ Тако се оне наводе у разним словенским језицима у књизи о словенској реченици Беличове и Ухлирове (Běličová, Uhlířová 1996).

${ }^{3}$ На истом мјесту Бондарко каже да се код таквих реченица не јавља својство пасивних реченица да семантички објекат одговара субјекту будући да субјекта немају, али да „се општа пасивна оријентација чува" (2011: 178).
} 
конструкцији: овдје је обезличен. Оне практично немају ништа заједничко с партиципским пасивним реченицама осим валенције за агентивну допуну.

Због свега истакнутог, на почетку је потребно утврдити однос ових реченица према пасивним. Потребно је, значи, прво дефинисати пасив као врсту дијатезе да би се могло рећи да ли и ове реченице спадају у пасивне реченице, тј. да ли и оне исказују пасивну дијатезу. Пасив је врста глаголске дијатезе код које се реченичним субјектом у номинативу не именује агенс, већ објекат радње (пацијенс), а предикат карактерише вршење радње у времену о коме реферише предикат; ${ }^{4}$ глагол отвара слабу валенцију за агентивну допуну (Падучева 1974: 225). По дефиницији, дакле, за исказивање пасива нужно је да реченица има субјекат у номинативу, којим се исказује објекат радње, пацијенс, из те позиције је потиснут актант агенс, и да се у позицији предиката налази прелазни глагол. Важно је нагласити и да у српском језику, као и другим словенским језицима, морфолошки ниво није довољан за исказивање пасивног стања; оно се исказује на нивоу реченице.

Ако погледамо горе наведене примјере, видјећемо да у њима нема субјекта у номинативу и он се не може увести. То говори да се ради о другачијем типу реченица. Јер присуство/одсуство субјекта у номинативу није споредни критеријум у разврставању реченица. Као што одређена комуникативна хијерархизација актаната доводи у пасивној реченици пацијенс у позицију синтаксичког субјекта, тако другачија њихова хијерархизација доводи до „испадања” пацијенса из позиције субјекта и, код разматраних реченица, из саме реченице и до немогућности увођења неког другог актанта у ту синтаксичку позицију у овим реченицама. А то правило - немогућност увођења синтаксичког субјекта у реченицу, карактеристично је за безличне реченице.

Ово је разлика која се огледа између пасивних и безличних партиципских реченица на синтаксичко-семантичком плану; у погледу позиција у реченици које заузимају актанти ситуација које именују глаголи. Има, међутим, важна разлика и на морфолошком плану. Код пасивних реченица партиципски дио предиката разликује лице и број, код безличних партиципских реченица партицип је граматички уподобљен како је образован и глаголски предикат код безличних реченица: јавља се искључиво у трећем лицу средњег рода једнине; глагол у трпном придјеву је обезличен. Тако је у наведеним примјерима [1], а то ће потврдити и сви други који се буду наводили у раду.

Тај поступак обезличавања предиката ових реченица, којим се блокира увођење реченичног субјекта - пацијенса, доводи до још једне разлике између њих и пасивних реченица. Наиме, познато је да се пасивне реченице јављају искључиво с прелазним глаголима, а образовања по моделу трпног придјева од непрелазних глагола представљају праве придјеве (Милошевић 1973: 426; Танасић 2014: 9, 41). Тако је у сљедећим примјерима:

${ }^{4}$ Дефиницију пасива као врсте дијатезе је код нас прва дала Ксенија Милошевић, на основу учења лењиградске школе седамдесетих година 20. вијека, (в. Храковский 1970), с тим што је додала елеменат који се тиче актуелности радње - како би се могла разграничити конструкција с трпним придјевом која исказује пасивну дијатезу од идентичне конструкције где је трпни придјев употријебљен у придјевском значењу, гдје, дакле, нема пасива (Милошевић 1972). Актуелност тада дате теорије пасива потврдио је Храковски и тридесет година касније - в. Храковский 2000. 
[2]

1. Проломиле се шљиве над прилазом, а Ђогат наочит и пропет, место мене најављује нам улазак у авлију (Стојановић, 35);

2. Цераром су сви разочарани, замерају му да није био довољно одлучан у важним тренуцима за земљу и да је био превише везан за Брисел (BН, 12. 03. 2018. Е);

3. у том контексту, уз став да је примарни циљ земље Европа и реалности да је народ проруски опредељен, власт покушава да нађе средину (BН, 12. 03. 2018. E);

4. Цијела породица била је преко ноћи разорена, а Ијан је био ријешен да иде до краја (ГС, 27. 02. 2018. Е).

Ово правило важи без изузетака; кад год се од непрелазног глагола образује форма по моделу трпног придјева, добије се прави придјев. Кад су пак у питању безличне партиципске реченице, њихов предикат се често образује и од непрелазних глагола и притом се не губи глаголска функција трпног придјева. Тако је у сљедећим примјерима:

[3]

1. Незванично сазнајемо да је на лицу места одмах [...] пронађено 21 чаура, а пуйано је из аутоматског оружја (П. 21. 09. 2013. Е);

2. На четворочасовној седници УО ниједном речи није поменут програм Културног центра [...], али је зато полемисано о рачуну за такси превоз (П. 12. 10. 2013. E);

3. Младобосанцима је суђено за велеиздају, јер је у том случају запрећена казна била смртна (ВН, 09. 01. 2014. Е);

4. Признају да са Арапима није разговарано о правним детаљима (НИН, 30. 01. 2014, 32);

5. Овде је обрнут случај о оног на који је наилажено (усмено излагање);

6. Прећено је и њој и њеној породици ако „било шта што не би требало изађе у јавност" (ВН, 17. 08. 2014. Е);

7. Тврди да је синоћ пуияано у области аеродрома Доњецк (ВН, 06. 09. 2014. Е);

8. Да је поступљено тако, можда би [...] данас био жив (П. 29. 10. 2014. Е);

9. У Врању му је два пута сућено за кривично дело убиства у покушају (BH, 15. 03. 2018. E);

10. Констатовано је да је у року од годину дана [...] поступљено у складу са 21 препоруком (П. 12. 10. 2013. Е).

Како се види, у овим примјерима ради се о глаголском предикату, различити непрелазни глаголи ступају у овај тип безлично оформљеног предиката.

Није ово коначан списак разлика између ових, безличних, и пасивних партиципских реченица. Познато је тако да се у неким случајевима из трпног придјева може елиминисати глаголска компонента и он се тада понаша као и прави придјев (Стевановић 1956: 209; Милошевић 1972; Танасић 2014). Кад је у питању предикат безличних партиципских реченица, могуће је да и у њему партицип изгуби глаголску компоненту. Међутим, тада се добија прилог, уп.: 
[4]

1. Твојој глави би суђено за вијенац се свој продати (Његош, 11);

2. Било је у њему неко саучешће, утеха, али и храброст и решеност: писано је, нема се куда (Станковић, 89);

3. Под њима, заморени, траже хлада, љубе се испод тих сувих грана, којима је суђено да угину ондје гдје су и одрасле - у лијепој, цвијетној планини (Ћипико, 31);

4. Кад је тако суђено, боље што пре, јер мање и жалости (Домановић, 68);

5. Очигледно, пуковнику није било суђено да на овој земљи проживи још неколико мирних месеци у рају који се зове одсуство његове жене (Андрић, $108)$;

6. Госпа Ноли није било суђено да види свој крај (Секулић, 7);

7. Али, иза прстена аустроугарских грађевина постојала је плитка река на коју нам је било забрањено одлазити (Капор, 55);

8. Упоредо с тим, највероватније ће бити и реконструисана Влада, а није искључено да нови министарски тим заузме место на Видовдан (BН, 03. 04. 2018. E);

9. Скоро две деценије је било политички забрањено говорити о албанском насиљу над српским народом на косову и Метохији (Печат, 23. 05. 2014, $32)$;

10. Чије име је било забрањено поменути у склопу обележавања победе над фашизмом (П. 24. 10. 2014. Е).

У деветом примјеру постојање одредбе која указује на трајање ситуације исказане предикатом јасно показује да трпни придјев нема глаголску вриједност. Посљедњи примјер се наводи као илустрација чињенице да се и у овим реченицама може појавити партиципски облик са могућношћу двозначног тумачења. Овдје се не може са сигурношћу тврдити да је из партиципског облика елиминисана глаголска компонента.

Овакви прилози могу се наћи и у другим позицијама у које долазе и други прилози:

[5]

1. У његовом образложењу измена закона о раду који је намргођено прочитао у скупштини није било ни слова од онога што пише у програму (НИН, 17. 07. 2014, 17);

2. Када им је речено да је Ћосић у Гроцкој, разочарано су протестовали (Печат, 23. 05. 2014, 32);

3. Демократска странка Србије аргументовано и озбиљно објашњава да не постоји више ниједан ваљан и важан разлог да Србија настави европске интеграције (П. 23. 02. 2014, 7);

4. Трајаће овај устав јер нико неће хтети или смети баш тако отворено да насрне на државни интегритет Србије (П. 23. 02. 2014, 7);

Дакле, мало је заједничког између ових реченица и пасивних реченица, разликују се по кључним карактеристикама: не образују се искључиво од прелазних глагола, кад се образују од прелазних глагола, обавезно се врши неутрализација 
прелазности, у реченици се не може појавити пацијенс у позицији синтаксичког субјекта; субјекат је блокиран, на морфолошком плану такође предикат/глагол је обезличен. Зеједничка им је валенција (слаба) за агентивну допуну и, видећемо, начин његовог исказивања. Очито много више немају него што имају заједничког. Зато их треба сматрати посебним типом реченица заједно с другим безличним реченицама.

У свим случајевима у којим су помињане безличне партиципске реченице у нас навођени су само примјери за прошлост. Међутим, оне имају потпунију парадигму глаголских облика, што ће показати сљедећи примјери.

[6]

1. Али давно је речено да слободу није довољно стећи, него је много важније постати достојан слободе (Андрић, 316).

2. Исакович онда рече Вишњевском, снуждено, да је Србима, колико је њему познато, обећано, свечано, да ће добити засебну, сербску, провинцију у Росији (Црњански 3, 86);

3. У Тверу је, поводом дана словенске писмености, у мају, говорено о Његошу (П. 13. 09. 2013);

4. Било им је речено да ће путовати по води, по Бегеју (Црњански 2, 51);

5. Било је планирано да изложбу отвори председник Србије Томислав Николић, али је због ситуације у земљи председник, скратио своју посету Француској (ВН, 24. 05. 2014. Е);

6. У саопштењу се наводи да су прва два Сухоја оборена јер су били у акцији којом је било планирано да бомбардују позиције доњецке војске. Оборили су их, како се прецизира, снаге доњецке милиције (BН, 29. 08. 2014. Е);

7. Њима неће бити дозвољено да се приближе зони опасности (П. 09. 10. 2013; Пупин, 5);

8. Према његовим речима, украјинским војницима биће предложено или да положе нову заклетву, или ће им бити омогућено да безбедно оду на територију украјинског копна (П. 06. 03. 2014. Е);

9. Али се не зна да ли ће принцези бити суђено (РТС, Дневник 2, 07. 11. 2014, 1945);

10. Када буде одлучивано о уставним амандманима, предложићу одредбу којом се локалним саветима омогућава да донесу одлуку о гарантовању статуса званичног језика" (BН, 08. 05. 2014. Е);

11. Уколико од Лондона буде тражено да бира између уласка у еврозону и иступања из ЕУ, неће много оклевати да окрене леђа Бриселу (П. 16. 01. 2014. E);

12. Би речено да се смије повести само по једна крава (Капор, 83);

13. Да ли би у било којој модерној држави било сматрано недостојним, недопустивим или противзаконитим да судија жртви (уколико је преживела) или њеној породици свечано уручи пресуду која у ствари није рехабилитовала њу, већ судство? (П. 01. 08. 2015. Е);

14. И данас се од тог, међу нами буди речено, помало беслеишем и дуваним (Кочић, 33);

15. Узгред буди речено, Живан је био прилично плашљив (Глишић, 132). 
Може се уочити да се за прошлост употребљава облик перфекта, плусквамперфекта и аориста. Такође, исказује се будућност обликом футура првог; облици футура другог нису забиљежене. Међутим, у исказивању значења које се примарно исказује обликом футура другог користи се и облик презента (10 и 11), као што је карактеристично и при исказивању активне и пасивне дијатезе. Предикат у облику футура другог би гласио у реченици 10: Када буде било одлучивано о уставним амандманима (в. Танасић 2014: 127). У савременом српском језику често се користи облик презента умјесто облика футура другог, кад се ради о глаголима свршеног вида, па и кад је у питању исказивање пасива реченицама са трпним придјевима (Танасић 2014: 119-136). Међутим, овдје наведени примјери показују нешто другачију ситуацију: облик презента употријебљен са несвршеним глаголима (10 и 11). Интересантно је напоменути и да се предикати јављају у оба модална облика - у потенцијалу (13) и императиву (14 и 15). Истина, облици императива су у устаљеној, фразеологизованој форми (слично је и у руском језику; в. АНСССР Грамматика: 381 ).

У нашој литератури већ је уочено да су ове реченице по значењу сличне неодређеноличним реченицама (Пипер, Антонић и др. 2005: 605), какве су сљедеће:

[7]

1. Рекли су му да дође ту и да ће добити пензију: одавно већ није ратник, а однедавно није ништа; узели су му и службу (Велмар Јанковић, 29);

2. Како су навели из тог министарства, државе чланице Европске уније морају да предузму мере смањења потрошње лаганих пластичних кеса (П. 11. 02. 2018. E);

3. Са РТС кажу да још нису донели одлуку (ВН, 18. 02. 2018. Е);

4. Олтар је најсветије место у православном храму и радујемо се што ће ускоро бити завршен - наводе у седишту Српске цркве (ВН, 25. 02. 2018. Е);

5. У плану је, како најављују у флотили, да се већ у априлу благослови 15 бродова ове јединице (ВН, 25. 02. 2018. Е);

6. Старешинама ће уз комплет службене торбе и униформе следовати и јакна - наводе у Министарству одбране (ВН, 23. 03. 2018. Е);

7. Укупна површина склоништа је 722 квадратна метра, објаснили су у Градској управи (ГС, 28. 02. 2018. Е).

За ове реченице је карактеристично да немају граматички субјекат, тј. вршиоци радње се не помињу (Пипер, Клајн 2015: 443), другачије казано - да им је субјекат „представљен специфичном нултом лексемом са значењем људи” (Бондарко 2011: 173; в. и Храковский 2011: 168-169). За њих је речено да се ријетко јављају у српском језику (Пипер, Клајн 2015: 443), а заиста се увијек могу преобразовати у безличне партиципске, осим ако није посриједи садашњост, нпр.:

1'. Речено му је да дође ту и да ће добити пензију;

3'. Са РТС је речено да још нису донели одлуку.

Партиципске безличне реченице имају сличности са безличним реченицама које се у српској литератури називају и обезличене реченице. 
Такве су сљедеће:

[8]

1. Путује се без обзира на ризик и стање културе (НИН, 18. 10. 2008, 46);

2. Како да се не посрће од умора и вртоглаве јурњаве (Андрић, 273);

3. Градило се, ко ће да окречи (НИН, 11. 03. 2010, 32);

4. оворило се само о царевој женидби (Андрић, 326);

5. У житију се наводи да су страдали у Панонији, на каменолому (НИН, 16. 04. 2009, 31);

6. У време британског Раџа говорило се да је све океј док је десет одсто Индије у некој побуни (П. 31. 08. 2013, 2);

7. па се очекивало да ће бити сходно и издашан према вршиоцима одреда (НИН, 10. 10. 2013, 25);

8. Како се наводи у саопштењу удружења пацијената, процењује се да око 200 пацијената у Србији више нема терапијских могућности (П. 16. 02. 2018. E);

9. У саопштењу Министарства одбране наводи се да је на дужност заменика директора [...] постављен пуковник (П. 17. 01. 2014. Е);

10. Ипак је, до краја, остала у вом позиву, присутна, препознатљива и поштована, каже се између осталог у телеграму (П. 11. 04. 2018. Е);

11. Управљање јавним инвестицијама такође је слабо, наведено је у извештају (П. 13. 02. 2018. Е);

12. Како је саопштено из Патријаршије, Комисија је консултовала и познате грчке и руске професоре (BН, 05. 03. 2018. Е);

13. У саопштењу о разговору је наведено да је двоје лидера разговарало (П. 10. 04. 2018. E).

Та сличност се огледа у сљедећем. И један и други тип реченица према себи има двочлане реченице са субјектом у номинативу. Њиме се по правилу на семантичком плану означава агенс радње исказане предикатом. У оба типа ових реченица долази до обезличавања предиката, што условљава немогућност увођења субјекта у реченицу, али у семантичкој структури реченице агенс остаје. И један и други тип се образују од непрелазних и прелазних глагола, при чему се код ових других обавезно елиминише прелазност. Код ових реченица с прелазним глаголом у предикату блокира се могућност увођења пацијенса у позицију субјекта.

О сличности међу овим реченицама говори и чињеница да би у многим случајевима ове реченице могле бити преобликоване у безличне партиципске замјеном форме предиката, без последица по друге елементе реченичне структуре и по садржај. У том погледу потребно је истаћи да преобликовање обезличене реченице у безличну партиципску реченице у неким случајевима захтијева промјену времена: облик перфекта у безличној партиципској има према себи облик презента у обезличеној и, ако је у перфекту партиципске реченице глагол био свршеног вида, он се у презенту мијења у несвршени. Тако би се обезличене реченице у примјерима 8-10 могле преобликовати у безличне партиципске, а безличне партиципске у примјерима 11-13 могле би се, опет, преобликовати у обезличене. Ради се о појави карактеристичној за административни и научни стил; у овим реченицама се саопш- 
тава да је то што је безличном реченицом исказано у неком тексту, документу, или потиче из неке институције или сл. (текст саопштења, уопште документ, сједиште неке институције $)^{5}$.

Има глагола који нису подједнако подобни за употребу у оба типа ових безличних реченица. Тако имамо примјере с безличним партиципским реченицама:

[9]

1. Нишка полиција, потврђено је јуче, ради на расвјетљавању околности (П. 07. 09. 2013. E);

2. Свакако, обелодањено је да саветници имају веће плате од њихових министара (НИН, 10. 10. 2013, 6);

3. Показано је да се реченице са значењем степена, како еквативне, тако и диферентивне, могу парцелисати (Реферат о докторској дисертацији).

Ради се о таквим случајевима гдје се пребацивањем безличне партиципске реченице у обезличену не би могла сачувати информација о томе је ли у питању прелазни глагол са блокираном позицијом за исказивање пацијенса или је у питању неки рефлексивни глагол без учесника вршиоца са значењем живо; обелоданити : обелоданити се, потврдити : потврдити се.

С друге стране, има доста глагола са рефлексивним се који могу имати обезличену реченицу, а не могу безличну партиципску реченицу. Такви би били: играти се, свађати се, радовати се, купати се, дивити се, подсмевати се... Сви глаголи који имају рефлексивно се не дозвољавају образовање партиципског предиката. Ови глаголи, међутим, дозвољавају образовање обезличених реченица - уп.: Ту је ... први пут видео како изгледа господски живот ... где се тихо разговара и лепо опходи међу собом (Андрић, 11); За парче сланине или прегршт брашна ишло се ноћу у далека села и преговарало и цеењкало са сумњивим људима (Андрић, 396).

Безличне партиципске реченице јављају се често са предикатом прелазних глагола. За ове реченице је карактеристично, видели смо, да не могу имати позицију субјекта у номинативу, коју би - да је могућа - попуњавала именица пацијенса. У овим реченицама нужно је неутралисати прелазност, што се врши на различите начине.

Има случајева, истина - малобројних, кад се у реченици не јавља никакво средство које неутралише глаголску прелазност, као што је у сљедећим примјерима:

[10]

1. Планирамо да обновимо кнез Михаилову улицу, у коју дуго година није улагано (П. 09. 11. 2014. Е);

2. Овде је писано слободније, и за публику већ упућену у књижевност (Скерлић, 10);

3. Скоро је кречено па се у соби осећао мирис креча (разговорни језик).

У оваквим случајевима неисказивање пацијенса је омогућено његовим непосредним постојањем, односно самоочевидношћу (Князев 2007: 558). Ипак, ово су ријетки случајеви, али заслужују да се помену.

${ }^{5}$ Ово је запазила Д. Савова (2014: 280). 
Често се прелазност глагола неутралише увођењем индиректног објекта, што омогућује образовање безличне реченице. Тако је у сљедећим примјерима.

[11]

1. У Удружењу војних пензионера истичу да још није донета ниједна пресуда којом је мериторно одлучено о праву војних пензионера, у складу са одлуком уставног суда (П. 07. 09. 2013, Треће доба, 7);

2. Изјавила је приговор против оптужнице, али о том приговору није одлучивано (П. 08. 02. 2018. Е);

3. У Тверу је, поводом дана словенске писмености, у мају, говорено о Његошу (П. 13. 09. 2013);

4. И о поменутим американским испитивањима говорено је опширно (Миланковић, 198);

5. О вези кнегиње Милице са породицом Немањић писано је у каснијим летописима, вероватно да би се одржао континуитет српске државе (BН, 01. 06. 2014. E);

6. На том пројекту је веома дуго рађено, али, ето, исплатило се (НИН, 06. 02. 2014, 55);

7. Радославу Брђанину је 2002. замерено за оно што је писао Илија Гарашанин у „Начертанију” пре више од 150 година, али и Његош 1846. године (П. 19. 02. 2014. Е).

8. Са истом праксом јесте настављено и у овом периоду, али некако неорганизовано (НИН, 14. 08. 2014, 55);

9. И када је помислио да је са свађом завриено, спремио се са супругом Верицом и троје деце, да крену за Нови Сад (ВН, 08. 11. 2014. Е);

10. Сви ђаци су препричавали доживљаја са излета, на школу је и заборављено (разг);

11. О спортским теренима је годинама сањано у нашем месту а сада су они изграђени код школе (разг.).

У овим примјерима имамо два различита начина неутрализације прелазности. У реченицама 1-5 глаголи у предикату могу истовремено имати ближи и даљи објекат. Увођењем даљег објекта неутралише се валенција за ближи објекат јер се тежиште преноси на даљи објекат. У примјерима 6-11 увођење даљег објекта искључује позицију за ближи објекат. Тако се стварају услови за образовање безличне партиципске реченице, исто као и кад су у питању обезличене реченице (Танасић 2014: 24-25).

Ипак има један случај када се безлична партиципска реченица може образовати с прелазним глаголом у предикату и да се искаже ближи објекат. Ради се о случају кад је ближи објекат у генитиву без предлога, што је карактеристика српског као и других словенских језика. Тако је у сљедећим примјерима.

[12]

1. Стога је приликом трансформисања деадјективне именице на позицији субјекта вођено рачуна о носиоцу особине/стања (Александра Ђорђевић, Филозофски факултет Ниш, дипломски рад);

2. У брашно је додавано боје да би изгледало као да је хлеб од црног брашна (разг.);

3. Пред Бадњи дан куповано је рибе да ручак буде богатији (разг.); 
4. Факултети су отварани, а није вођено рачуна да ли ће бити посла за оне који их заврше (разг.);

5. О проблемима у вези са студијама дискутовало се често, али није налажено снаге да се они отклоне (разг.);

6. Није тражено начина да се млади ангажују око решавања њихових проблема (разг.).

У српском језику познате су реченице у активној форми са овако исказаним ближим објектом (в. Танасић 2012: 29).

Као и код активних и обезличених реченица, и у овим реченицама објекат у генитиву се јавља у два случаја - кад је у питању именица која исказује значење партитивности, реченице 1-3, или кад се ради о словенском генитиву, односно при одрицању, како је у реченицама 4-6. Ове реченице се понашају идентично обезличеним реченицама.

У српском језику многи глаголи су сентенцијално прелазни, што значи да захтијевају реченицу као допуну глаголу у управној клаузи. Тако је у сљедећим примјерима.

[13]

1. А Јулици, девојчици од дванаестак година, наређено је било да крене с адвокатом и са свима потребним стварима, то јест, да се коначно пресели код сестре (Секулић, 29);

2. Али је у исти мах одлучено и да се подигне нов и модеран даљан испод Таш-Моруништа (Алас, 27);

3. Наређено ми је да те вежем, чича-Аћиме снуждено рече апсанџија с катанцем у рукама (Ћосић, 95);

4. Тешке гранате су засипале шуму, те је наређено да се људи и коњи склоне од погледа с аероплана (Јаковљевић, 22);

5. Било им је речено да ће путовати по води, по Бегеју (Црњански 2, 51);

6. Исакович онда рече Вишњевском, снуждено, да је Србима, колико је њему познато, обећано, свечано, да ће добити засебну, сербску, провинцију у Росији (Црњански 3, 86);

7. И да је из Цариграда већ поручено: да је француски конзул у Травнику и даље „девлет-мусафир” (Андрић, 45);

8. Договорено је да Сабором 2016. године, као први међу једнакима, председава царигрдски патријарх Вартоломеј, а поглавари осталих православних цркава седеће са његове леве и десне стране (ВН, 15. 03. 2014. Е);

9. Најпре ми је понуђено да у храму Успења пресвете Богородице у Петници урадим одређене послове на простору њене порте (П. 16. 02. 2014, 20);

10. Речено нам је да треба да бранимо отаџбину, што сам прихватио као свету обавезу и велику част (П. 05. 10. 2013, 13);

11. Свакако, обелодањено је да саветници имају веће плате од њихових министара (НИН, 10. 10. 2013, 34);

12. Тврђено је да се реч „Косово” поред речи „Бог” најчешће помиње у Горском вијенцу (И. Андрић, Његош као трагични јунак косовске мисли, Политика 04. 11. 2013); 
13. Уколико од Лондона буде тражено да бира између уласка у еврозону и иступања из ЕУ, неће много оклевати да окрене леђа Бриселу (П. 16. 01. 2014. Е);

14. Један од истраживача тешко се разболео на броду, па је са овога радиограмом тражено да се са америчке обале хитно пошље хидроавион (Алас, 80).

15. Од стране екселенције нам је великодушно одобрено и да можемо да имамо добре односе и са Русијом, и са Кином, и са САД (П. 20. 09. 2014. Е).

И међу овим примјерима највише је оних са обезличеним предикатом од свршених глагола у управној клаузи, мада нису искључиво такви; има и несвршених глагола, примјери 12-14. Наравно, овакви предикати од несвршених глагола јављају се и у неким другим врстама реченица, в. [3] 1-7, 9, 11; [11] 2-6. Кад је посриједи прошлост, по правилу се глаголима свршеног вида исказује референцијалност, као што је увијек код исказивања прошлости у српском језику (Танасић 2014: 111-118), док се глаголима несвршеног вида и на плану прошлости и на плану будућности може исказивати и референцијалност, [13] 12, и нереференцијалност, [13] 13, 14. Избацивањем субјекта који на семантичком плану има значење агенса глагол отвара валенцију за агентивну допуну. Она је слаба, не попуњава се често. Посљедњи примјер илуструје случај кад је та валенција попуњена конструкцијом од (стране) + генитив, карактеристичном за српски језик. Као и кад су посриједи пасивне рефлексивне и партиципске реченице, те обезличене реченице (в. Танасић 2014), и овдје се на агенс може указивати и посредно (в. [14]).

Ове реченице имају свој пандан и међу асиндетским реченицама (детаљније в. Танасић 2018), о чему свједоче сљедећи примјери.

[14]

1. И законодавство ЕУ [...] у потпуности важи за „Јужни ток”, речено је за „Политику" у кабинету европског комесара за енергетику (П. 24. 01. 2014, 1);

2. Студенти Универзитета у Београду (УБ), буџетски и самофинансирајући, биће ослобођени многих такси које су до сада плаћали [...], одлучено је данас на седници Савета тог универзитета (BН, 29. 10. 2014. Е);

3. У редовне услуге које улазе у износ школарине, и не наплаћује се додатно, убрајају се и сви облици наставе и предиспитне обавезе предвиђене студијским програмом, одлучено је на седници и наведено да одлука ступа на снагу осмог дана од објављивања у универзитетском гласнику (ВН, 29. 10. 2014. Е);

4. Српско народно веће (CHB) има право да постави захтев за испуњење права која сматра важнима, а исто тако свако те захтеве има право да подржи или да не подржи, саопштено је данас из кабинета (BН, 18. 02. 2018. Е);

5. „Тужилац је на лицу места и руководи увиђајем”, саопштено је из владе (П. 22. 02. 2018. Е);

6. Управљање јавним инвестицијама такође је слабо", наведено је у извештаjу (П. 13. 02. 2018. Е);

7. Нисмо упознати са овом информацијом - саопштено је у Председништву БиХ (BН, 07. 03. 2018. Е);

8. Полицијски службеници настављају провере у циљу расветљавања осталих околности у вези са злоупотребом приликом издавања документације 
којом се доказује право на повраћај имовине, наведено је у саопштењу (П. 07. 09. 2013, 9);

9. У образложењу такве одлуке наведено је: „имајући у виду чињеницу да је реч о Стефану Немањи - творцу државе [...] треба да заузме репрезентативно - централно споменичко место у граду (П. 16. 03. 2018. Е);

10. Нишка полиција, потврђено је јуче, ради на расвјетљавању околности под којим су упућене веома озбиљне претње директору Клиничког центра Ниш (П. 07. 09. 2013, 9);

11. На Пантићеве тврдње за „Политику” је реаговао и Оливер Ивановић [...], који, примећено је, с Пантићем и после избора укршта копља и мора се приметити да међу њима двојицом непрестано севају варнице (П. 01. 01. 2014. E).

Безлична клауза најављује туђи говор, а клауза у којој се износи туђи говор може бити означена наводницима или је без њих (о различитим варијацијама исказивања туђег говора у српском језику (в. нпр. Ковачевић 2012). Безличне партиципске реченице се врло често јављају међу објекатским и оваквим асиндетским реченицама.

Укратко. Безличне партиципске реченице су једночлане реченице, без субјекта, код којих се предикат образује помоћу трпног придјева, и то у безличном облику. Иако се њихов предикат образује с трпним придјевом као и код пасивних партиципских реченица, оне се од ових разликују по битним својствима - на морфолошком и синтаксичком плану, које их управо повезују с безличним реченицама: имају обезличен предикат, блокирана им је позиција субјекта, образују се од непрелазних и прелазних глагола, при чему ови други у њима губе валенцију за допуну ближег објекта. У српском језику прелазност глагола се неутралише на различите начине. Честе су ове реченице и са сентенцијално прелазним глаголима, гдје се прелазност задовољава зависном клаузом. Безличне партиципске реченице су по многим својим карактеристикама најближе обезличеним реченицама, мада има и извјесних разлика међу њима - у погледу глагола с којим се могу образовати, као и у погледу могућности исказивања агентивне допуне.

Анализом грађе утврђене су још неке досад непомињане карактеристике ових реченица. Тако, показано је да оне не исказују само прошлост, већ имају потпуну парадигму глаголских облика у српском језику. Иако се често употребљавају заједно са обезличеним реченицама, има случајева кад и нису међусобно замјењиве. Тако су оне неподобне за исказивање садашњости, а не могу се образовати од рефлексивних глагола; обје те могућности су доступне обезличеним реченицама. Јављају се од глагола свршеног и несвршеног вида, у погледу разликовања референцијалности/нереференцијалности немају ништа посебно у односу на српску језичку ситуацију. Овим реченицама најчешће се износи информација о вршењу/извршењу глаголске радње, много рјеђе, према анализираној грађи, исказује се стање. Кад се исказује стање, реченични предикат с обезличеним обликом трпног придјева се понаша као прилог. Безличне партиципске реченице су честе у савременом српском језику, у свим његовим функционалним стиловима, зато заслужују да буду подробно истражене како би добиле потпун опис и право мјесто у граматикама. 


\section{Лuтература}

АНСССР Грамматика. Шведова Н. Ю. (ред.). Русская грамматика, том 2: Синтаксис. Москва: Наука, 1980.

Бондарко А. В. Категоризация в системе грамматики. Москва: Язык сславянских культур, 2011.

Князев Ю. П. Грамматическая семантика. Русский язык в типологической перспективе. Москва: Языки славянских культур, 2007.

Ковачевић М. „О граматичко-стилистичком терминосистему туђег говора.” Српски језик, XVII (2012): 13-38.

Милошевић К. „Неки аспекти семантичког односа конструкција пасивен (са трпним придјевом) и рефлексивне у савременом српском језику.” Књижевни језик, I/3-4: 63-86.

Падучева Е. В. О семантике синтаксиса : Материалы к трансформационной грамматике русского языка. Москва: Издательство „Наука”, 1974.

Пипер П., Антонић И., Ружић В., Танасић С., Поповић Љ., Тошовић Б. Синтакса савременога српског језика: проста реченища. У редакцији академика Милке Ивић. Београд: Институт за српски језик САНУ, Београдска књига; Нови Сад: Матица српска, 2005.

Пипер П., Клајн И. Нормативна граматика српског језика, ијекавско издање. Измијењено и допуњено (према другом екавском издању). Нови Сад: Матица српска, 2015.

Савова Д. Деагентивността в българскияезик и нейното изразяване (в съпоставка със сръбския език). Софија: Св. Климент Охридски, 2014.

Симић Р., Јовановић Ј. Српска синтакса I.-II. Београд: Научно друштво за неговање и проучавање српског језика, 2002.

Симић Р., Јовановић Ј. Српска синтакса III.-IV. Београд: Научно друштво за неговање и проучавање српског језика, 2002а.

Станојчић Ж., Поповић Љ. Граматика српског језика. - 10. издање. Београд: Завод за уџбенике и наставна средства.

Стевановић М. „Глаголски облици пасива.” Наш језик, нова серија, VII/4 (1956): 205-216.

Стевановић М. Савремени српскохрватски језик II : Синтакса. - 5. издање. Београд: Научна књига, 1991.

Танасић С. „Безличне реченице с уопштеним агенсом.” Из синтаксе српске речениие. Београд: Београдска књига, 2012: 17-34.

Танасић С. „Пасивне конструкције са трпним придјевом.” У Танасић 2014: 7-97.

Танасић С. „Пасивне конструкције за исказивање будућности.” У Танасић 2014: 119-136.

Танасић С. Синтакса пасива у савременом српском језику. Београд: Београдска књига, 2014.

Танасић С. „Асиндетске реченице.” Синтакса сложене реченице у савременом српском језику. У редакцији академика Предрага Пипера. Нови Сад: Матица српска, Београд: Институту за српски језик САНУ, 2018: 597-633. 
Тополињска 3. ,'Падеж' и 'глаголски род' - две стратегије граматикализације односа између 'предиката' и његових 'аргумената'." Јужнословенски филолог, 42 (1996): 1-9.

Храковский В. С. Категория залога : Материальл конференции. Ур. Храковский. Ленинград: Наука, 1970.

Храковский В. С. „Диатези и залоги (тридцать лет спустя).' Слово в тексте : Сборник статей к семидесятию академика Ю. Д. Апресяна. Москва, 2000: 466-474.

Храковский В. С. „Пассивные конструкции.” Бондарко А. В. (ред.) Теория функцииональной грамматики. Персональность. Залоговость. Москва: Академия наук СССР, Институт лингвистических исследований; Санкт-Петербург: Наука, 2011: 141-180.

Běličová H., Uhlířová L. Slovanská věta. Praha: Euroslavica, 1996.

Moskovljević Popović J. Ogledi o glagolskoj potkategorizaciji. Beograd: Čigoja štampa, 2007.

Mrazović P., Vukadinović Z. Gramatika srpskog jezika za strance. - Drugo, prerađeno i dopunjeno izdanje. Sremski Karlovci - Novi Sad: Izdavačka knjižarnica Zorana Stojanovića, 2009.

\section{Извори}

Алас - Петровић Алас М. Роман јегуља. Београд: АСК.

Андрић - Андрић И. Травничка хроника. Београд: Нолит, 1981.

АСК - Антологија српске књижевности, електронска библиотека. Београд: Учитељски факултет.

Велмар Јанковић - Велмар Јанковић С. Дорћол. Београд: АСК.

ВН - Вечерње новости, дневни лист. Београд.

Глишић - Глишић М. Приповетке. Београд: АСК.

ГС - Глас Српске, дневни лист. Бања Лука.

Домановић - Домановић Р. Мртво море. Београд: АСК.

Е - електронско издање новина.

Јаковљевић - Јаковљевић С. Српска трилогија. Књига друга. Београд: АСК.

Капор - Капор М. Најбоље године и друге приче. Београд: АСК.

Кочић - Кочић П. Изабрана дела. Београд: АСК.

Миланковић - Миланковић М. Кроз васиону и време. Београд: АСК.

НИН - НИН, недељне информативне новине. Београд.

П. - Политика, дневни лист. Београд.

Печат - Печат, недељне новине. Београд.

РТС - Радио телевизија Србије.

Секулић - Секулић И. Кроника паланачког гробља. Београд: АСК.

Скерлић - Скерлић Ј. Историја новије српске књижевности. Београд: АСК.

Станковић - Станковић Б. Нечиста крив. Београд: Аск. 
Стојановић - Стојановић М. М. Родослов. Ниш: Просвета, 1999.

Ћипико - Ћипико И. Пауции. Београд: АСК.

Ћосић - ћосић Д. Корени. Београд: АСК.

Црњански 2 - Црњански М. Сеобе 2. Београд: Нолит, 1973.

Црњански 3 - Црњански М. Сеобе 3. Београд: Нолит, 1973.

Срето 3. Танасич

БЕЗЛИЧНЫЕ ПРИЧАСТНЫЕ ПРЕДЛОЖЕНИЯ В СЕРБСКОМ ЯЗЫКЕ

\section{Резюме}

В работе речь идет об одном типе безличных предложений в сербском языке, которые известны и другим славянским языкам и которые в сербской научной литературе до сих пор не были обработаны. Они упоминаются только в более новых грамматиках сербского языка. Это одночленные предложения - предложения без субъекта, у которых предикат образуется с помощью страдательного прилагательного. Предикат находится в безличной форме в отличие от пассивных причастных предложений, у которых со страдательным прилагательным образуется личная глагольная форма. Такие безличные предложения иллюстрирует следующий пример: Речено нам је да треба да бранимо отаџбину. Эти предложения отличаются от причастных пассивных предложений несколькими значимыми критериями. Наряду с наличием страдательного прилагательного в предикате - не таким же способом, общим для них является единственно то, что в семантическом плане обязательно имеют актант агенс, который в предложении может быть и высказан, но в позиции агентивного дополнения, для которого глагол имеет слабую валентность. В семантической структуре этих предложений обязательно имеется агенс, по этому свойству они сходны с рефлексивными безличными предложениями, известными в сербской литературе как обезличенные, какой является напр.: У Београду се говори о Конгресу слависта. В работе показывается, что обезличенные предложения часто могут преобразоваться в причастные безличные и наоборот. Между тем, имеются случаи, когда это невозможно.

Хотя у нас приводятся только примеры этих предложений с предикатом в форме перфекта, у них есть целая парадигма глагольных форм сербского языка. Эти предложения образуются от глаголов совершенной и несовершенной формы и не приносят никаких особенностей в высказывании оппозиции референциальность/нереференциальность глагольного действия по отношению к уже известному способу высказывания этой оппозиции в сербском языке. Также, они образуются с непереходными и переходными глаголами, причем у переходных глаголов обязательно проводится нейтрализация переходности различными способами.

Ключевые слова: сербский язык, предложения, безличные причастные предложения, пассивная диатеза, обезличивание, нейтрализация переходности. 